\title{
Disciplinærretlig skyld og straf i danske fængsler ${ }^{1}$
}

Hans Jørgen Engbo, cand.jur., tidligere fængselschef i Danmark og direktør for Kriminalforsorgen i Grønland. Medlem af den rets- og kriminalpolitiske tænketank Forsete.

\begin{abstract}
This article describes disciplinary sanctions applied to imates in Danish prisons. The aricle begins with an explanation of the purpose of disciplinary punishment and of the legal basis for its use. The article then provides an analysis of administrative practices illustrated by descriptions of a few representative disciplinary cases decided by the prisons and appelate cases decided by the courts and the Department of Prisons and Probation. In relation to legal bases, the analysis reveals significant shortcomings regarding both the provision and the assessment of evidence as well as the choice of sanction. The article concludes with a series of recommendations to the authorities.
\end{abstract}

\section{Keywords}

Prison, disciplinary liability and sentencing, solitary confinement, legality, proportionality. Fængsel, disciplinærretligt ansvar, sanktionsudmåling, isolation, legalitet, proportionalitet.

\section{Indledning}

Den danske straffuldbyrdelseslov (sfbl.) hjemler fængselsmyndighederne adgang til at anvende isolation (kaldet strafcelle) som disciplinærstraf over for indsatte, som begår disciplinbrud. Brugen af isolation som disciplinærstraf har givet anledning til en del kritik både internt i Danmark og fra internatinale kontrolorganer. Kritikken har blandt andet handlet om isolationens helbredsskadende virkninger, negligering af internationale anbefalinger, dobbeltbestrafning og skrøbelige processuelle retssikkerhedsgarantier (se bl.a. Engbo \& Smith 2012, Smith m.fl. 2013, Dignity 2017 b og c, Verland \& Christoffersen 2017, Kessing 2019, Engbo 2019 og Folketingets Ombudsmand 2020).

Målet med denne artikel er

- at klarlægge retsgrundlaget for ansvarspålæggelse og sanktionsudmåling i disciplinærsager i fængslerne, navnlig i sager, som fører til anvendelse af strafcelle,

1. Title in English: Disciplinary responsibility and punishment in Danish penal institutions 
- at analysere håndteringen i praksis af disse led i behandlingen af disciplinærsager, og

- at pege på muligheder for styrkelse af sagsbehandlingen på de nævnte områder.

Artiklen er baseret på traditionel retsdogmatisk metode med en indledende redegørelse for det officielle formål med disciplinærstraf i fængslerne og en gennemgang af retsgrundlaget for anvendelse af disciplinærstraf. Dernæst følger en kritisk analyse af den administrative praksis i fængslerne og i Direktoratet for Kriminalforsorgens afgøreler i klagesager med særlig fokus på ansvarsspørgsmålet, herunder tilvejebringelse og bedømmelse af beviser, og sanktionsudmålingen. Isolationens helbredsskadende virkninger vil ikke blive behandlet i denne artikel. ${ }^{2}$ Væsentlige processuelle aspekter er kritisk belyst af Kessing (2019) og Folketingets Ombudsmand (2020) og vil kun i begrænset omfang blive berørt i artiklen. Enkelte steder er retstilstanden i andre nordiske lande inddraget $\mathrm{i}$ analysen.

\section{Disciplinærstraffenes formål og karakter}

\subsection{Formålet med disciplinærstraf}

Disciplinærstraffesystemet er i forarbejderne til straffuldbyrdelsesloven karakteriseret som »en afgørende forudsætning dels for kriminalforsorgens muligheder for at løse sine sikkerheds- og ordensmæssige opgaver [og] for tilvejebringelsen af en rimelig hverdag i institutionerne. Det tilføjes, at disciplinærstraffesystemet i fængslerne ligesom det almindelige straffesystem er begrundet i hensyn til repression samt general- og specialprævention (betænkning nr. 1181/89, s. 239). Denne karakteristik er også brugt af Rentzmann m.fl. (2003, s. 163) og Schiøler \& Dragsted (2017, s. 349), som begge tillige opstiller en definition af disciplinærstraf som »en administrativ, pønal reaktion over for indsatte på en ikke tilladt adfærd«. ${ }^{3}$

Senest har Justitsministeriet i en lovbemærkning karakteriseret strafcelle som »et nødvendigt redskab til at sikre orden og sikkerhed i kriminalforsorgens institutioner« (FT 2018/19 (1. samling), tillæg A, s. 22).

Medens Rentzmann m.fl. og Schiøler \& Dragsted således i deres definition særligt har fokuseret på disciplinærstraffens pønale karakter, har lovforarbejderne lagt hovedvægten på disciplinærstraffens funktion som sikkerheds- og ordensredskab med fremadsrettet sigte. Der kan være gode grunde til at ned-

2. Isolationens helbredsskadende virkninger er grundigt dokumenteret. Se nærmere Engbo \& Smith (2012 s. 125 ff.) og Smith \& Koch (2019 s. 109 ff.) om isolationens virkninger.

3. Denne definition ses ikke at have grundlag i straffuldbyrdelseslovens forarbejder og står derfor som forfatternes egen forståelse af disciplinærstraffens væsen og funktion. Det bemærkes, at alle tre forfattere på udgivelsestidpunkterne var chefer i DfK. 
tone det pønale element, således som det er sket i de nævnte lovforarbejder, og som Norges Høyesterett klart og tydeligt har markeret med disse ord: „Selv om disiplinærreaksioner (...) har en allmenn- og individualpreventiv virkning, er formålet ikke først og fremst av pønal karakter, men å opprettholde ro og orden innenfor fengslet« (Norsk Rettstidende 2003, s.1100).

\subsection{Disciplinærstraffenes art og karakter}

Straffuldbyrdelsesloven hjemler brug af tre former for disciplinærstraf: advarsel, bøde og strafcelle (sfbl. § 68, stk. 1).

Advarsel skiftede ved straffuldbyrdelseslovens ikrafttræden i 2001 status fra at være et mere eller mindre uformelt alternativ til en disciplinærstraf til at blive den mildeste form for disciplinærstraf. Sigtet hermed var, at de retssikkerhedsgarantier, som er forbundet med ikendelse af disciplinærstraffe også skal finde anvendelse i sager, der afgøres med en advarsel. ${ }^{4}$

En bøde kan højst udgøre et beløb svarende til en uges beskæftigelsesvederlag (2020-niveau: 400 DKK) og kan inddrives ved modregning i den indsattes beskæftigelsesvederlag (sfbl. § 69).

Ordet »strafcelle« betegner, trods ordlyden, ikke en celle, men derimod en disciplinær sanktion bestående i højst fire ugers tidsbestemt isolation (»udelukkelse fra fællesskab«), som gennemføres i en almindelig celle/stue, enten den indsattes egen eller en celle i en særlig (isolations)afdeling (sfbl. $\S 70) .{ }^{5}$ Praktiske hensyn og skånsomhedshensyn - men ikke pønale hensyn er bestemmende for valget af anbringelsesform. Strafcelle er en mindre indgribende form for isolation end den kollusionsforebyggende isolation under varetægtsfængsling, idet strafcelle alene griber ind i fællesskabsretten. Den indsatte har principielt fortsat ret (og pligt) til beskæftigelse og bevarer også retten til at kommunikere med omverdenen gennem ukontrolleret brevveksling, telefonering, besøg og udgang. En eller flere af disse rettigheder kan dog samtidig være frataget ved særskilt afgørelse, hvis forebyggende hensyn gør dette nødvendigt.

\section{Retsgrundlag for anvendelse af disciplinærstraf}

Disciplinærretten hører hjemme i krydsfeltet mellem strafferet, forvaltningsret og menneskeret. En disciplinærstraf er grundlæggende et forvaltningsretligt indgreb, som kræver iagttagelse af forvaltningsrettens spilleregler, herunder proportionalitetsgrundsætningen og officialprincippet. ${ }^{6}$ Indgrebets karakter af straf medfører, at også grundlæggende strafferetlige principper anvendes i sagsbehandlingen. Det gælder bl.a. legalitetsprincippet

4. Betænkning nr. 1181/1989, s. 240.

5. Betegnelserne »celle« og »stue« bruges i daglig tale i henholdsvis lukkede og åbne fængselsafdelinger som betegnelser for den indsattes værelse, som i loven noget misvisende benævnes »opholdsrum«.

6. Jf. vejl. nr. 9084 af 30.01.2019 (disciplinærstrafvejledningen), punkt 1.2, 2. afsnit. 
og principper for tilvejebringelse og bedømmelse af beviser. Endelig rummer de mest indgribende former for disciplinærstraf nogle menneskeretlige aspekter, som må kræves iagttaget i den disciplinærretlige praksis. Nogle af de vigtigste menneskeretlige spørgsmål er behandlet af Kessing (2019) og vil derfor ikke blive omtalt her. I denne artikel vil dansk ret blive holdt op imod anbefalinger fra Europarådets Ministerkomité (De Europæiske Fængselsregler) og fra FN's generalforsamling (Nelsom Mandela Rules). Desuden vil bestemmelser i Den Europæiske Menneskerettighedskonvention (EMRK) samt enkelte afgørelser fra Den Europæiske Menneskerettighedsdomstol (EMD) blive inddraget i beskrivelsen af retsgrundlaget og senere i analysen af praksis.

\subsection{Disciplinærstrafbare gerninger}

I overensstemmelse med det strafferetlige legalitetsprincip (jf. straffelovens § 1) må anvendelse af disciplinærstraf forudsætte, at det i loven - eller i administrative forskrifter udstedt i henhold til loven - udtrykkeligt er angivet, hvilke nærmere bestemte former for adfærd, som kan medføre disciplinærstraf. En sådan bestemmelse skal søges formuleret så præcist som muligt. ${ }^{7}$ I straffuldbyrdelsesloven er det bestemt, hvilke gerninger (handlinger eller undladelser), som skal medføre disciplinærstraf (sfbl. § 67). ${ }^{8}$ Loven overlader med (for?) bred bemyndigelse både til justitsministeren og til de lokale kriminalforsorgsmyndigheder at fastsætte regler om anvendelse af disciplinærstraf for overtrædelse af bekendtgørelser og lokalt fastsatte regler (§ 67, stk. 8 og stk. 9). De lokale regler herom skal behørigt kundgøres for de indsatte (sfbl. § 123 a, stk. 2). De såkaldte normalreaktionsskemaer er vejledninger for forhørslederne og kan ikke samtidigt optræde som ordensregler for de indsatte, med mindre de tydeligt er formuleret og kundgjort som sådanne for de indsatte.

Det kan diskuteres, om legalitetskravet er opfyldt i bestemmelsen om, at disciplinærstraf kan anvendes ved overtrædelse af straffelovgivningen, »når overtrædelsen tillige indebærer en selvstændig krænkelse af orden eller sikkerhed i fængslet« (sfbl. § 67, nr. 7). Det er næppe i tilstrækkelig grad forudsigeligt for de indsatte, hvilken adfærd, som efter en forhørsleders opfattelse vil krænke orden eller sikkerhed. Det burde specificeres i loven, hvilke delikter i straffelovgivningen, som (tillige) kan medføre disciplinærstraf.

\subsection{Disciplinærretligt ansvar}

Det er i dansk retspraksis og i den juridiske litteratur lagt til grund, at anvendelse af disciplinære sanktioner forudsætter, at den indsatte kan pålægges

7. Jf. justitsministerens svar på. spørgsmål nr. 13 fra Folketingets Retsudvalg vedrørende forslag til lov om ændring af straffeloven og forskellige andre love (L 139-2018/19, 1. samling). Se også De Europæiske Fængselsregler (Europarådet 2020), regel 57-2 a, jf. bemærkningerne hertil i Ministerkomitéens dokument af 20. februar 2020, CM(2020)17add2, og Mandela-reglerne (FN 2018), rule 37 (a).

8. Jf. betænkning nr. 1181/89 om en lov om fuldbyrdelse af straf mv. s. 241. 
disciplinært ansvar efter de almindelige strafferetlige principper (Greve 2002, s. 109; Engbo 2005, s. 244 f; Schiøler \& Dragsted 2017, s. 355; FOB 2020-14). Betingelserne for at pålægge en indsat disciplinært ansvar er herefter, at det anses for bevist,

1. at den indsatte har foretaget en gerning, som efter straffuldbyrdelsesloven kan medføre disciplinærstraf,

2. at gerningen kan tilregnes den indsatte som forsætlig eller uagtsom (der skal foreligge skyld),

3. at den indsatte ikke var utilregnelig i gerningsøjeblikket, og

4. at der ikke forelå objektive straffrihedsgrunde (nødværge, nødret, samtykke $\mathrm{mv}$.).

Bevishåndteringen forudsættes som nævnt at foregå på samme måde som i straffesager, hvor tilvejebringelsen af beviserne foregår efter principperne om bevisumiddelbarhed og mundtlighed. Bedømmelsen af beviserne sker efter grundsætningen om bevisbedømmelsens frihed (jf. retsplejelovens $\S 896,2$. pkt.), som indebærer, at forhørslederen frit skal kunne vurdere værdien af det bevismateriale, som er tilvejebragt under forhøret; dette gælder såvel vægten af hvert enkelt bevis i sagen som den samlede afvejning af alle de fremlagte beviser. Ved beviskrav forstås den grad af sikkerhed, som på grundlag af bevisførelsen skal være opnået, for at et bestemt forhold kan anses for bevist. Det må kræves, at den indsattes skyld er sandsynliggjort i en sådan grad, at der ikke består nogen rimelig tvivl herom. Hvis der efter bevisførelsen og bevisbedømmelsen består en rimelig tvivl om indsattes skyld, skal der således ske frifindelse (in dubio pro reo). ${ }^{9}$ Det afgørende er ikke, om forhørslederen selv føler sig overbevist om den indsattes skyld. Der må ikke objektivt set være rimelig tvivl om den indsattes skyld i det indberettede forhold.

\subsection{Valg og udmåling af disciplinærstraf}

\subsubsection{Strafferetlig proportionalitet}

Disciplinærstraf skal udmåles under hensyn til overtrædelsens art og omfang (sfbl. §§ 69, stk. 1, og 70, stk. 1). Bestemmelsen er udtryk for det strafferetlige proportionalitetsprincip, hvorefter straffens strenghed skal stå i forhold til forbrydelsens grovhed. Straffen skal i den forstand opleves som retfærdig.

Det er fastsat i lovens $\S 68$, stk. 2, hvilke gerninger, som kan føre til anvendelse af strafcelle. Legalitetsmæssigt svækkes bestemmelsen noget ved en upræcis formuleret hjemmel til at bruge strafcelle ved »andre grove eller oftere gentagne forseelser« (nr. 7). Det er ikke særlig forudsigeligt, hvad en

9. Se eksempelvis Justitsministeriets redegørelse i høringssvar vedrørende Kommissionens grønbog om uskyldsformodningen af 11. oktober 2006, jf. Folketingets Retsudvalgs bilag 29 (alm. del) 2006-07. 
forhørsleder vil vurdere som en "grov« forseelse. Bestemmelsens betydning er (modsætningsvis) at fastslå, at alle andre forseelser end de oplistede kun kan straffes med advarsel eller bøde, med mindre de gentages oftere (dvs. to eller flere gange).

Varigheden af strafcelle fastsættes efter sfbl. § 70, stk. 1, til højst fire uger. Omfatter en disciplinærsag flere forhold, anvendes det strafferetlige princip om modereret kumulation, jf. strl. § 88, stk. 1, 1. pkt., hvorefter retten i sådanne tilfælde fastsætter en fælles straf for alle lovovertrædelserne inden for den foreskrevne strafferamme eller, hvis flere strafferammer kommer i betragtning, den strengeste af disse. I modsætning hertil står absolut kumulation, som indebærer, at straffen fremkommer ved sammenlægning af straffe udmålt for hvert enkelt forhold. Direktoratet for Kriminalforsorgen (DfK) har oplyst til Folketingets Ombudsmand (FO), at der ved fastsættelse af disciplinærstraf for flere forhold ikke anvendes absolut kumulation (FO 2020, s. 20 f.).

Lovens angivelse af en maksimumstraf bliver delvis illusorisk, når flere strafcellekendelser fuldbyrdes i forlængelse af hinanden. De Europæiske Fængselsregler (Europarådet 2020, regel 60.6.e), siger om sådanne situationer:

"Where a punishment of solitary confinement is imposed for a new disciplinary offence on a prisoner who has already spent the maximum period in solitary confinement, such a punishment shall not be implemented without first allowing the prisoner to recover from the adverse effects of the previous period of solitary confinement.»

Den danske regering har imidlertid - som det eneste af Europarådets medlemslande - i en fodnote til reglerne forbeholdt sig retten til ikke at efterkomme anbefalingen om en sådan recover-pause mellem flere strafcellefuldbyrdelser. Der er således ikke noget loft over den samlede varighed af strafcelleafsoning, hvilket den danske regering også udtrykkeligt har markeret i fodnoten. ${ }^{10}$ Dansk ret er i denne sammenhæng i klar strid med Mandela-reglerne (FN 2018, regel 43-1 [b]), som anbefaler forbud mod isolation i mere end 15 sammenhængende dage.

\subsubsection{Normalreaktioner}

Siden 1988 har de danske fængsler i indbyrdes samarbejde udfærdiget skemaoversigter over vejledende normalreaktioner i henholdsvis åbne og lukkede fængsler. I skemaerne angives niveauet for disciplinærstraffe i typiske tilfælde, men det er understreget, at disciplinærstraffen altid skal udmåles efter en konkret vurdering af omstændighederne i den enkelte sag (Engbo 2005, s. 264; Schiøler \& Dragsted 2017, s. 354f).

De vejledende normalreaktioner blev i sin tid fastlagt af fængslerne for at undgå en tættere styring af praksis fra DfK, som havde fundet det betænke-

10. Note 1 i Recommendation Rec(2006)2-rev of the Committee of Ministers to member States on the European Prison Rules, 1. juli 2020. Se også Folketingets Ombudsmand 2020, s. 12. 
ligt, at praksis havde udviklet sig forskelligt fra fængsel til fængsel. ${ }^{11}$ Senere har direktoratet - politisk bestemt - flere gange blandet sig i styringen af normalreaktionerne ved at diktere skærpelser af reaktionerne for bestemte forseelser. Det skete i 2002 angående udeblivelse fra udgang, ${ }^{12}$ i 2004 angående narkotikaforseelser mm., ${ }^{13}$ i 2016 angående indsmugling og besiddelse af mobiltelefoner mm. ${ }^{14}$ og i 2017 angående »upassende sprogbrug og adfærd", jf. omtalen heraf nedenfor. I 2004 blev det pålagt fængslerne at anvende strafcelle i stærkt udvidet omfang (Engbo 2005, s. 241 f; Smith m.fl. 2013, s. 184), og historien gentog sig i 2016 som led i en skærpet indsats mod uretmæssig besiddelse af mobiltelefoner. ${ }^{15}$

I 2017 blev normalreaktionerne for upassende sprogbrug og adfærd - af DfK også betegnet "grimt sprog og dårlig opførsel« - skærpet efter indstilling fra en taskforce nedsat af justitsministeren. ${ }^{16}$ Som eksempler på adfærd, som skal medføre strafcelle, nævner DfK bl.a. »at give nogen fingeren, at rulle med øjnene eller slå hårdt i bordet for at understrege en pointe«. Loven indeholder ikke direkte hjemmel til at anvende disciplinærstraf i disse tilfælde, og det synes usikkert, i hvilket omfang der er udsendt lokale regler, som i sammenhæng med sfbl. §67, nr. 9, kan hjemle disciplinærstraf. Ikendelse af strafcelle kræver tillige, at forseelsen konkret bedømmes som grov eller oftere gentagen, jf. § 68, stk. 2, nr. 7. Sanktionering af upassende sprogbrug kan efter omstændighederne være i strid med EMRK art. 10 om ytringsfrihed. I sagen Yankov v. Bulgaria (2003) fandt EMD, at det havde været uberettiget at ikende en indsat syv dages isolationsstraf for at have betegnet fængselsbetjente som »velnærede dovendyr« (well-fed idlers) og »enfoldige bønderkarle» (simple villagers). Domstolen udtalte bl.a., at "[t]he need to ensure that civil servants enjoy public confidence in conditions free of undue perturbation can justify an interference with the freedom of expression only where there is a real threat in this respect. ${ }^{17}$ En finger eller rullende øjne kan måske ses som en lettere intimiderende opførsel, men næppe som en reel trussel mod den offentlige tillid til fængselspersonalet. Det burde i øvrigt yde tilstrækkelig beskyttelse for fængselspersonalet - som det gør for alle andre offentligt ansatte - at strfl.

11. Se nærmere betænkning nr. 1181/89 om en lov om fuldbyrdelse af straf mv. s. 238 f.

12. Jf. DfK's skrivelse af 28. februar 2002, j.nr. JUR 02-129-2.

13. Notat af 21.10.2004 om normalreaktioner på områderne narkotika, ulovlige dopingmidler og vold og trusler mod personalet, j.nr. JUR 04-034-108.

14. Jf. to skrivelser af 15.04.2016 fra DfK til områdekontorerne om skærpelse af praksis i henholdsvis åbne og lukkede fængsler, sagsnr. 16-740-0007.

15. Jf. lovforslag nr. L 186/2015-16, s. 4, samt Justitsministeriets pressemeddelelse af 4. marts 2016 med tilhørende faktaark.

16. Jf. indstillingen »Anbefalinger til initiativer som kan styrke sikkerheden for medarbejdere i Kriminalforsorgen«, afgivet den 27. april 2017 af en taskforce om medarbejdersikkerhed, nedsat af justitsministeren i februar 2017. Indstillingen førte til en skrivelse af 26. juni 2017 (med bilag) fra DfK til kriminalforsorgsområderne mm. vedrørende ændring af normalreaktioner i sager om vold og trusler om vold samt upassende sprogbrug og adfærd, sagsnr. 17-40-0114.

17. Yankov v. Bulgaria, dom 11.12.2003, app.nr. 39084/97, § 142. 
$\S 121$ hjemler straf til »den, som med hån, skældsord eller anden fornærmelig tiltale overfalder [en offentligt ansat] under udførelsen af hans tjeneste eller hverv«.

\subsubsection{Lovbunden disciplinærstraf}

Ved en lovændring i 2016 overgik disciplinærstraf fra at være et indgreb, som kunne anvendes, til at være et indgreb, som skal anvendes. ${ }^{18}$ Denne ændring strider fundamentalt mod disciplinærstraffens væsen. Der vil altid forekomme tilfælde, hvor en forhørsleder finder det unødvendigt at ikende disciplinærstraf for en forseelse, men efter lovændringen er der ingen vej udenom; der skal ikendes unødvendige disciplinærstraffe. På det principielle plan har ændringen ikke den store betydning, idet en sag altid vil kunne afgøres med en advarsel. Men i praksis synes lovændringen i kombination med den reviderede vejledning om normalreaktioner at være opfattet nærmest som en tjenstebefaling om i nærmere bestemte tilfælde at anvende strafcelle, også selv om sagen langt fra har den exceptionelle karakter, som efter De Europæiske Fængselsregler kræves for anvendelse af strafcelle (Europarådet 2020, regel 60.6.c).

Gennem denne ændring og gennem de gentagne pålæg til Kriminalforsorgen om at skærpe disciplinærstraffene har politikerne ændret disciplinærstraffens funktion fra at være et fængselsfagligt redskab til at være et politisk redskab, som reelt tjener til skærpelse af den straf, som idømmes af retten (idet de fleste strafcellesager vedrører forhold, som tillige behandles som straffesager). Disciplinærstraffen får herved karakter af en administrativt fastsat tillægsstraf, som det fra politisk side er pålagt fængslerne at idømme uden nogen konkret fængselsfaglig vurdering af behovet for at anvende disciplinærstraf eller for disciplinærstraffens strenghed.

\subsubsection{Proportionalitet med fremadrettet sigte}

Det strafferetlige proportionalitetsprincip er bagudrettet, idet det relaterer til en begået strafbar gerning. Proportionalitet kan også anskues med fremadrettet sigte ved at relatere til indgrebets formål (Greve 2008, s. 12). I loven fremhæves dette udtrykkeligt i forbindelse med udelukkelse af indsatte fra fællesskab på ubestemt tid som forebyggende indgreb. Indgrebet skal være nødvendigt, og det må ikke foretages, »hvis det efter dets formål og den krænkelse og det ubehag, som indgrebet må antages at forvolde, ville være et uforholdsmæssigt indgreb « (sfbl. §63, stk. 1, og stk. 6). Tilsvarende formuleringer ses i lovbestemmelser om andre integritetskrænkende indgreb (magtanvendelse, håndjern, sikringscelle mm.). ${ }^{19}$ Endvidere er der for disse indgreb lovfæstet et skånsomhedsprincip, som fastslår, at indgrebene skal gennemføres så skånsomt, som omstændighederne tillader. Principielt har disse lovbestemmelser begrænset

18. Sfbl. § 67 som ændret ved lov nr. 641/2016.

19. Sfbl. § 60, stk. 4 (undersøgelse), § 62, stk. 3 (magtanvendelse), § 65, stk. 2 (håndjern) og $\S 66$, stk. 2 (sikringscelle). 
selvstændig betydning, idet de blot markerer, hvad der i forvejen er gældende i kraft af den forvaltningsretlige grundsætning om proportionalitet (inkl. skånsomhed), som stiller krav om netop nødvendighed, forholdsmæssighed og skånsomhed (Mortensen 2009, s. 4; Westerhäll 2006, s. 185; Schiøler 2012, s. 110 ff; Schiøler \& Dragsted 2017, s. 291; Fenger 2018, s. 361). Det er i den forvaltningsretlige litteratur fremhævet, at grundsætningen har stor praktisk betydning i forhold til afgørelser, der indeholder et element af sanktion over for en borger (Christensen 1997, s. 201; Andersen 2007, s. 112), og dette element er jo selve kernen i disciplinærstraffen.

Den samme anvendelse af proportionalitetsprincippet gælder i strafferetsplejen og i menneskeretten. ${ }^{20}$ EMRK beskytter i art. 8 retten til respekt for privatliv, hvortil efter EMD's praksis bl.a. hører retten til at etablere og udvikle relationer til andre mennesker. ${ }^{21}$ Indgreb i denne ret, $f x$ ved tvangsmæssig udelukkelse af en person fra samvær med andre mennesker, kan dog efter artiklens stk. 2 foretages, hvis det sker i overensstemmelse med loven og er nødvendigt i et demokratisk samfund af hensyn til bl.a. den offentlige tryghed, forebyggelse af uro eller forbrydelse, beskyttelse af sundheden eller sædeligheden eller beskyttelse af andres ret og frihed.

Mandela-reglerne (FN 2018, regel 36) kræver, at disciplin og orden skal håndhæves "with no more restriction than is necessary to ensure safe custody, the secure operation of the prison and a well ordered community life«. Den Europæiske Torturforebyggelseskomité (CPT 2011, afsnit 55d) fremhæver ligeledes nødvendighed som et afgørende krav bag brugen af isolation.

I Norge har Sivilombudsmannen (2019, s. 16) stillet krav om, at adgangen til fællesskab kun begrænses »i samsvar med prinsipper om lovmessighet, nødvendighet og forholdsmessighet«.

DfK har i Kriminalforsorgens principprogram (1993) fremhævet den forvaltningsretlige grundsætning om proportionalitet i form af et princip om mindst mulig indgriben, som betyder, at der ikke må anvendes mere magt eller flere restriktioner end nødvendigt. I disciplinærstrafvejledningen har DfK udtrykkeligt understreget, at almindelige forvaltningsretlige grundsætninger indgår i retsgrundlaget for anvendelse af disciplinærstraf. ${ }^{22}$

Selv om straffuldbyrdelseslovens markering af den forvaltningsretlige proportionalitetsgrundsætning af ukendte årsager ikke er medtaget i lovens afsnit om disciplinærstraf, må proportionalitetsgrundsætningen anses for gældende med samme styrke som ved de øvrige indgreb. Man kan ikke vælge at se bort fra en rodfæstet forvaltningsretlig grundsætning, som tillige er gældende i menneskeretlig sammenhæng, og som understreges i internationale anbefalinger. Det ville tage sig besynderligt ud at operere med en praksis, hvorefter en bestemt »normalreaktion« skal ikendes, selv om den konkret skønnes

20. Hvad angår strafferetsplejen, henvises til retsplejelovens $\S 770$ b og til strafferetsplejeudvalgets betænkning nr. 1358/1998 om varetægtsfængsling i isolation, afsnit 8.3.3.

21. Jf. eksempelvis Pretty v. UK, dom 29.04.2002, app. nr. 2346/02, § 61.

22. Jf. vejl. nr. 9084 af 30.01.2019 (disciplinærstrafvejledningen), punkt 1.2, 2. afsnit. 
unødvendig som redskab til at sikre orden og sikkerhed i fængslet og/eller fremstår som et uforholdsmæssigt indgreb.

Forhørslederen i en disciplinærsag bør således ud fra disse udlægninger af proportionalitetsgrundsætningen kun vælge den mest indgribende disciplinærstraf - strafcelle - hvis der i den enkelte sag foreligger overbevisende argumenter for, at dette er nødvendigt for at sikre orden og sikkerhed i fængslet.

De fastsatte normalreaktioner blev ved deres tilblivelse i slutningen af 1980'erne tænkt som maksimumreaktioner. I Kriminalforsorgen har man imidlertid udlagt de seneste skærpelser sådan, at man nu skal arbejde med minimumreaktioner for visse forseelser, jf. Kriminalforsorgens udviklingsplan 2018-21: „De seneste skærpelser har medført minimumsstraffe for at have mobiltelefoner eller andet kommunikationsudstyr, for at udøve vold eller true med det og for at overtræde det indendørs rygeforbud. ॥ $^{23}$ En sådan tolkning ses ikke at have hjemmel i loven.

Det skal tilføjes, at almindelige strafudmålingshensyn, jf. straffelovens kap. 10, efter praksis vil kunne indgå ved udmålingen af disciplinærstraf (Engbo 2005, s. 264; Schiøler \& Dragsted 2017, s. 360; FO 2020, s. 20). Forhørslederen bør bl.a. tage hensyn til særlige forhold hos den indsatte (alder og helbredsforhold, herunder fysisk og psykisk skrøbelighed), som kan gøre det særlig belastende at være anbragt $\mathrm{i}$ isolation.

Når det gælder fuldbyrdelse af strafcelle, bør skånsomhedsprincippet indebære, at sanktionen som udgangspunkt fuldbyrdes i den indsattes egen celle/stue og ikke i en fremmed celle på en særlig isolationsafdeling, idet loven tillader begge disse fuldbyrdelsesmåder (sfbl. § 70, stk. 2). Skånsomhed kan også fremmes ved at lade den indsatte opholde sig i cellen/stuen med åbenstående dør; der er i loven intet krav om indelåsning (jf. eksempel fra Norge: Nytrøen 2019, s. 200).

\section{Strafcelle i praksis}

\subsection{Kvantitativ brug af strafcelle}

I praksis har fængslerne i de senere år øget brugen af isolation som disciplinærstraf. Fra 2001 til 2019 blev det årlige antal kendelser vedrørende ubetinget strafcelle mere end tredoblet (se illustration 1).

23. Tryg på arbejde - stolt hjem. Kriminalforsorgen i udvikling 2018-21. Publikation udgivet af DfK om Kriminalforsorgens udviklingsplan 2018-21, s. 23. Link: https://www. kriminalforsorgen.dk/wp-content/uploads/2018/10/udviklingsplan-2018-21.pdf (læst 27.10.2020). Kursiveret her. 


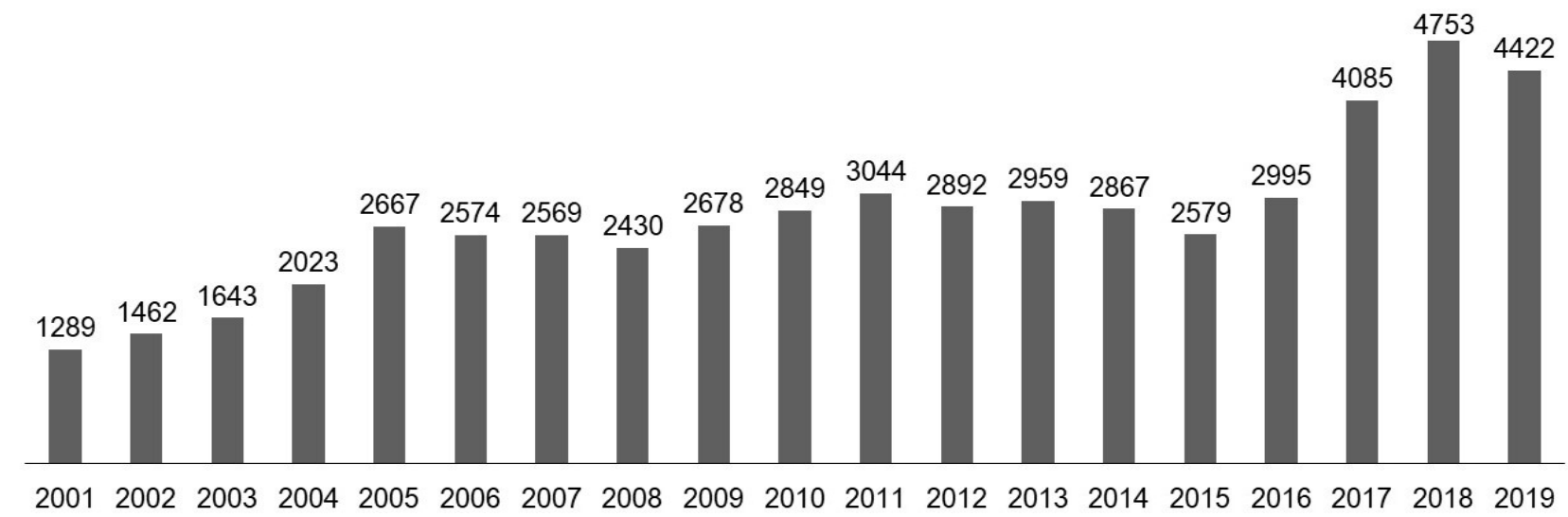

Illustration 1: Antal årlige kendelser om ubetinget strafcelle. (Kilde: Kriminalforsorgens årlige statistikberetninger)

Disse tal underdriver endda den reelle stigning i brugen af strafcelle, idet der tillige, navnlig efter 2016-reformen, er sket en markant stigning i varigheden af de ikendte disciplinærstraffe. Således er antallet af kendelser om ubetinget strafcelle i 15 dage eller mere steget eksplosivt i løbet af de seneste år fra syv i 2015 til 705 i 2019 - en hundrededobling (!) på fire år:

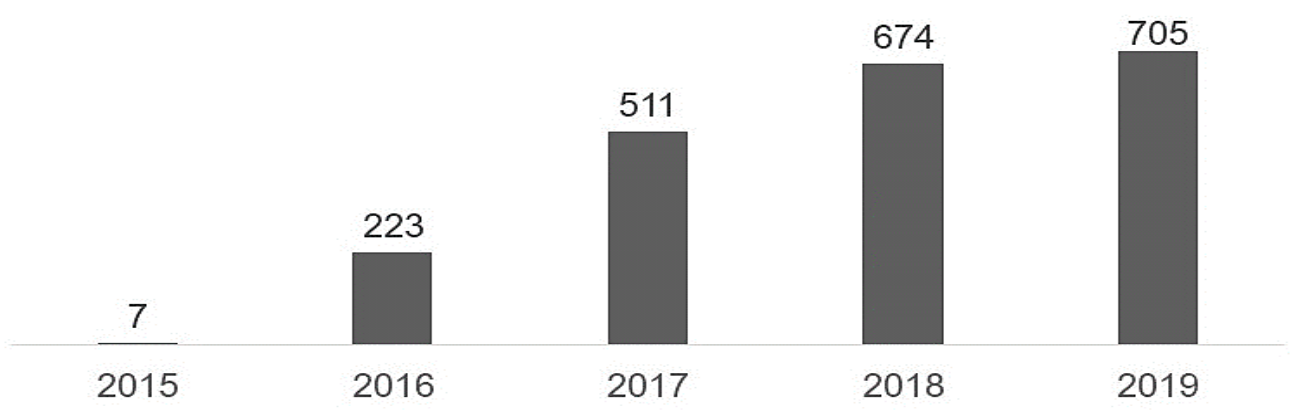

Illustration 2: Antal årlige kendelser om ubetinget strafcelle i 15 dage eller mere. (Kilde: Kriminalforsorgens årlige statistikberetninger)

Isolation i mere end 15 sammenhængende dage betegnes i Mandela-reglerne (FN 2018, regel 44) som langvarig isolation, som ifølge reglerne helt bør forbydes (regel 43-1 [b]). I straffuldbyrdelsesloven (§ 70, stk. 1) er der ikke desto mindre hjemmel til som disciplinærstraf at udelukke indsatte fra fællesskab i indtil fire uger, og det kan desuden forekomme, at to (eller flere) langvarige strafcellekendelser fuldbyrdes i direkte forlængelse af hinanden (jf. ovenfor afsnit 4.3.1).

\subsection{Administrativ praksis}

Administrativ praksis indgår i retskildehierarkiet, men på lavere trin end de retskilder, som er omtalt ovenfor i hovedafsnit 3. Vejledningerne vedrørende normalreaktioner har karakter af oversigter over administrativ praksis. 
Med henblik på at klarlægge administrativ praksis i disciplinærsagerne er der søgt aktindsigt i

- forhørsprotokollater vedrørende de seneste 50 afholdte disciplinærforhør i fængsler og arrester i Område Sjælland forud for den 8. november 2019,

- alle DfK's klageafgørelser vedrørende disciplinærstraf i fem år frem til den 12. november 2019 - i alt 161 afgørelser og

- alle domstolskendelser vedrørende strafcelle siden straffuldbyrdelseslovens ikrafttræden i 2001 - i alt 13 afgørelser.

En gennemgang af disse i alt 224 sager danner grundlag for en praksisanalyse, hvis væsentligste resultater $\mathrm{i}$ kort form vil blive beskrevet nedenfor og holdt op mod den ovenstående redegørelse for de højere rangerende retskilder.

Det kan være af interesse at vide, at før 1980 blev alle disciplinærforhør i fængslerne ledet af juridisk uddannede fængsels- og vicefængselsinspektører. I løbet af 1980'erne blev opgaverne i alle fængsler delegeret til etatsuddannelse ledere af fængslernes sikkerhedstjeneste (ledende overvagtmestre), og i de efterfølgende årtier er forhørsledelsen gradvis blevet delegeret til etatsuddannelse enhedsledere og fængselsbetjente, som har gennemgået et forhørslederkursus på Kriminalforsorgens Uddannelsescenter.

\subsubsection{Tilvejebringelse af beviser}

En disciplinærsag indledes på baggrund af en indberetning (eller flere) om regelstridig adfærd - i praksis kaldet en »rapport«. Rapporten foreholdes den indsatte under et disciplinært forhør. DfK's disciplinærstrafvejledning (punkterne 2 og 3) siger om gennemførelse af forhøret bl.a.:

»Forhørslederen afgør (...), om disciplinærsagen kan gennemføres på grundlag af de foreliggende indberetninger, eller om det af hensyn til klarlæggelse af sagens omstændigheder er påkrævet at indhente yderligere oplysninger eller foretage afhøringer af personale eller indsatte. (...)

I nogle tilfælde vil det være påkrævet at indhente yderligere indberetninger eller foretage afhøringer af personale eller medindsatte. Endvidere kan det i visse tilfælde være nødvendigt at foretage genafhøring af såvel den indsatte som af vidner.»

Hvis den indsatte i det hele erkender rapportens rigtighed, afgør forhørslederen normalt sagen på dette grundlag. Hvis den indsatte helt eller delvis bestrider rapportens rigtighed, bør kravene om mundtlighed og bevisumiddelbarhed føre til yderligere undersøgelser, herunder afhøring af rapportskriveren og eventuelle andre vidner. Dette sker imidlertid ikke i praksis at dømme ud fra de analyserede sager. I nogle sager har forhørslederen noteret i forhørsprotokollen, at han »har talt med« rapportskriveren eller et andet vidne og refereret, hvad den pågældende har sagt, men dette er tilsyneladende sagt under en uformel snak og dermed uden overværelse af det obligatoriske forhørsvidne, og uden at den pågældende har godkendt referatet. Formelle vidneafhøringer og kontraafhøringer forekommer ikke i en eneste af de 50 
undersøgte sager, og i mange tilfælde har forhørslederen afgjort sagen med rapporten som eneste »bevis«, selv om en rapport alene burde have funktion som grundlag for en sigtelse og ikke som bevismateriale. Til sammenligning nævnes, at politirapporter som udgangspunkt ikke anerkendes som beviser i en straffesag (Smith m.fl. 2005, s. 616; Toftegaard Nielsen 2020, s. 189).

\section{Eksempel 1 (Storstrøm Fængsels afgørelse af 15.10.2019):}

Under forhørsprotokollens rubrik »Bevisbedømmelse« henvises til, at »de mange vidner til episoderne vægter tungt: fængselsbetjente, sygeplejerske og tandlæge, der hver især beskriver de enkelte episoder og bekræfter indsattes højrøstede meget krænkende sprogbrug " - dette til trods for at ingen vidner er afhørt under forhøret, og ingen referater af uformelle samtaler med vidner findes i forhørsprotokollen.

\section{Eksempel 2 (Jyderup Fængsels afgørelse af 09.10.2019):}

I rapporten oplyses, at indsatte »flere gange har været et emne på de morgenmøder, som afholdes på behandlingsafdelingen«, uden at det er nærmere oplyst, hvad der er talt om på møderne. Under forhørsprotokollens rubrik »Bevisbedømmelse« er følgende noteret: »Rapporten lægges til grund for disciplinærsagens behandling samt udtalelser fra behandlerne og betjente på morgenmøderne på behandlingsafdelingen«. Forhørslederen har imidlertid ikke afhørt - eller talt med - mødedeltagerne, hvis nærmere identitet ikke er oplyst i forhørsprotokollen, og det er heller ikke oplyst, hvad udtalelserne på møderne går ud på.

Det forekommer, at indsatte forklarer sin adfærd med psykiske problemer, fejlmedicinering mv., men sådanne forklaringer har ikke givet forhørsledere anledning til at indhente lægelige udtalelser eller afhøre sundhedspersonale med henblik på at belyse tilregnelighed eller eventuelle personlige forhold af betydning for spørgsmålet om disciplinærretligt ansvar og for sanktionsudmålingen.

Spørgsmål om tilregnelse (forsæt eller uagtsomhed) og om objektive straffrihedsgrunde (nødværge, nødret, samtykke mv.) ses heller ikke at have været genstand for bevisførelse. Ombudsmanden har i en klagesag vedrørende strafcelle (FOB 2020-14) påpeget manglende opmærksomhed på spørgsmålet om tilregnelse.

Forhørspraksis ses således at være i åbenbar strid med disciplinærstrafvejledningen og med kravene om mundtlighed og bevisumiddelbarhed. DfK ses ifølge klagebesvarelserne ikke at have fundet anledning til at påpege disse mangler.

\subsubsection{Bevisbedømmelse og beviskrav}

Bevisbedømmelsen indskrænker sig i langt de fleste tilfælde, hvor der ikke foreligger tilståelse, til en henvisning til rapporten. I forhørsprotokollen ses følgende typiske - yderst kortfattede - notater under rubrikken »Bevisbedømmelse« i sager, hvor indsatte har bestridt rapportens rigtighed:

_ $\quad$ «Rapporten samt selve hashen.»

- »Rapporterne vedrørende sprogbrug og de nægtede urinprøver fra modulet, gentagelsesvirkning, lægges til grund.» 
- „Rapportens ordlyd. Ulovlige genstand som er vedhæftet rapporten.»

_ »Det findes bevist gennem rapporter samt effekter."

- Ud fra rapportens ordlyd findes det bevist at indsatte har udvist upassende sprogbrug samt adfærd. Samt at han i første omgang har indrømmet at have sparket i transportbilen«.

- »Ved rapportens indhold findes det bevist at indsatte har været i besiddelse af væske og batterier til en E-cigaret i indsattes tobaksskab på afdelingen."

DfK har i klageafgørelserne ikke fundet anledning til at kritisere, at bevisbedømmelsen er baseret alene på rapporten, hvilket har logisk sammenhæng med, at man har godkendt, at der ikke foretages afhøringer og kontrafhøringer af vidner, når den indsatte bestrider rapportens rigtighed.

Beviskravene synes i den administrative praksis at være noget lempeligere end tilsvarende inden for strafferetsplejen. Således er det i flere sager oplyst, at politiet på grund af utilstrækkelige beviser har opgivet påtale i anmeldte sager om vold og trusler begået af indsatte, men ikke desto mindre har forhørslederen i disciplinærsagen fundet den indsatte skyldig i den anmeldte lovovertrædelse. DfK har i flere klagesager godkendt denne praksis med ordene: „Det forhold at politiet har valgt ikke at rejse tiltale i sagen, mener vi ikke, kan føre til et andet resultat«. ${ }^{24}$ En domstolsafgørelse har med samme ordvalg godkendt en disciplinærstraf, selv om politiet havde opgivet sigtelsen med den begrundelse, at det ikke kunne forventes, at den pågældende ville blive fundet skyldig i sigtelsen. ${ }^{25}$ I modsætning hertil har områdekontoret i Hobro anset en disciplinærstraf af strafcelle i 7 dage for at være uberettiget:

»Henset til, at Østjyllands Politi den 12. marts 2018 besluttede at opgive sigtelsen for forholdet begået natten til den 1. januar 2018 finder Områdekontoret at [den indsatte] har været uberettiget placeret i en strafcelle i 7 dage. ${ }^{26}$

Under domstolsprøvelse af en disciplinærstraf, som en indsat var ikendt trods frifindelse i en straffesag, argumenterede DfK for, at den indsatte godt kunne være skyldig i den disciplinære forseelse, selv om han var blevet frifundet under straffesagen. Retten fandt imidlertid at måtte lægge bevisvurderingen under straffesagen til grund og fandt det herefter »ikke tilstrækkelig sikkert godtgjort, at der var grundlag for at idømme [den indsatte] strafcelle i 8 dage «. ${ }^{27}$

Der savnes således en klar linje i praksis angående bevis for strafbar adfærd, som det øvrige retsvæsen ikke har funder tilstrækkeligt bevist.

24. Jf. eksempelvis DfK's klageafgørelse af 16.05.2019 vedrørende Enner Mark Fængsels afgørelse af 22.09.2019 (burde nok være 2018).

25. Kendelse afsagt den 27.09. 2019 af Retten i Horsens.

26. Områdekontor Midt- og Nordjyllands afgørelse af 28.02.2019.

27. Kendelse afsagt den 11.07.2013 af Retten i Glostrup. 
Som omtalt i afsnit 4.2. gælder det strafferetlige princip in dubio pro reo også i disciplinærsager. Hvis der efter bevisførelsen og bevisbedømmelsen består en rimelig tvivl om indsattes skyld, skal der ske frifindelse. Ud fra formuleringerne i forhørsprotokollerne og i DfK's klageafgørelser ses dette princip ikke at blive tillagt større betydning i disciplinærsagerne. Eksempelvis kan det undre, at den omstændighed, at politiet/anklagemyndigheden på grund af bevisnød opgiver videre strafforfølgning, ikke synes at bringe en forhørsleder eller en klagesagsbehandler i rimelig tvivl om, hvorvidt den indsatte er skyldig i en lovovertrædelse.

Som påpeget af Folketingets Ombudsmand (2020, s. 25 ff.) er hjemmelsangivelsen i disciplinærsagerne ofte mangelfuld, ikke mindst i de mange sager, som har primær hjemmel i sfbl. § 67, nr. 8 og nr. 9, om disciplinærstraf for overtrædelse af regler fastsat af henholdsvis justitsministeren og kriminalforsorgsområdet, når det i disse reglerne er bestemt, at overtrædelse kan medføre disciplinærstraf. Der savnes i afgørelserne en præcis henvisning til de konkrete ministerielle eller lokale regler, som hjemler disciplinærstraffen. Den samme mangel lider de fleste af DfK's klageafgørelser af. En hyppigt brugt hjemmelsformulering ser således ud: „Du og din klient kan læse reglerne om disciplinærstraf for upassende adfærd i sfbl. § 67, nr. 9«. ${ }^{28}$ Der savnes en supplerende henvisning til den relevante lokale bestemmelse. I nogle tilfælde har DfK tilføjet: »jf. husorden«, men uden en præcis angivelse af de(n) relevante bestemmelse(r) i denne husorden. ${ }^{29}$ DfK's praksis kan undre, når det ifølge direktoratets egen vejledning om behandling af sager om disciplinærstraf mv. (punkt 9) kræves, at notatet i forhørsprotokollen bl.a. skal indeholde oplysning om, »[h]vilke bestemmelser der anses for overtrådt med angivelse af loven, bekendtgørelsen og/eller den interne regel samt [en] præcis angivelse af paragraf, stykke, nummer eller litra« (kursiveret her).

\subsubsection{Valg og udmåling af disciplinærstraf}

Det fremgår tydeligt af fængslernes og arresternes afgørelser og af DfK's klageafgørelser, at de fastsatte normalreaktioner følges nøje. Det er sjældent at se afvigelser begrundet i skærpende eller formildende omstændigheder.

DfK har i forbindelse med klagesagsbehandling fastslået, at den lovfæstede maksimale varighed af strafcelle (4 uger) relaterer til den enkelte forseelse og ikke til den enkelte disciplinærsag og har samtidig anerkendt absolut kumulation, således at en disciplinærsag, som vedrører flere forhold, kan resultere i strafcelle med en samlet varighed, der overstiger fire uger.

\section{Eksempel 4 (DfK's klageafgørelse af 21.04.2017):}

Københavns Fængsler ikendte den 3. oktober 2016 en indsat 32 dages strafcelle, heraf 3 dage betinget, ved absolut kumulation (simpel addition) af 21 dage for besiddelse af ulovligt kommunikationsudstyr, 5 dage for besiddelse af ulovlig medicin, 3 dage for

28. DfK's klageafgørelse af 09.07.2018 vedrørende Herstedvester Fængsels afgørelse af 23.10.2017.

29. DfK's klageafgørelse af 09.05.2019 vedrørende Kolding Arrests afgørelse af 05.11.2018. 
ulovlig besiddelse af rygeredskaber og 3 dage (betinget) for ulovlig kommunikation på gårdtur. De 3 dages betinget strafcelle blev den følgende dag gjort ubetinget efter en ny ligeartet forseelse. Samtidig besluttede fængslet dog at ændre de to afgørelser til samlet 28 dages strafcelle.

I DfK's klageafgørelse hed det bl.a.: »Det fremgår af straffuldbyrdelseslovens $\S 70$, at der kan ikendes strafcelle som disciplinærstraf med en varighed af maksimalt 4 uger. Bestemmelsen regulerer det enkelte forhold, som der ikendes straf for. Der kan således ikendes en disciplinærstraf på mere end 4 uger, hvis der er tale om, at flere forskellige forhold behandles under samme forhør." DfK kritiserede fængslets efterfølgende korrigering af udmålingen fra 32 til 28 dage. $^{30}$

Der er også eksempler på anvendelse af absolut kumulation, men med samtidig respekt for den generelle maksimumstraf på fire uger:

\section{Eksempel 5 (DfK's klageafgørelse af 20.12.2017):}

Københavns Fængsler ikendte den 20. juni 2017 en indsat 28 dages strafcelle ved sammenlægning af 14 dage for besiddelse 23,9 gram hash, 3 dage for besiddelse af en tilvirket gaffel og 15 dage for besiddelse af mobiltelefon og oplader - i alt 32 dages strafcelle, som blev konverteret til 28 dage.

DfK fandt afgørelsen korrekt, idet »antallet af strafcelledage (...) er korrekt udmålt, herunder i forhold til straffuldbyrdelseslovens $\S 70$, stk. 1《.

Praksis angående kumulation har således været noget vaklende, men må anses for afklaret med DfK's seneste oplysning til ombudsmanden, om at der ikke anvendes absolut kumulation i disciplinærsager (jf. ovenfor afsnit 4.3.1).

Det forvaltningsretlige proportionalitetsprincip, som kræver nødvendighed og forholdsmæssighed i relation til formålet med et indgreb, spiller tilsyneladende ikke nogen rolle i disciplinærsagerne bedømt ud fra de analyserede afgørelser. Om en (streng) disciplinærstraf er nødvendig for opretholdelse af orden og sikkerhed i fængslet, kunne bl.a. overvejes i de - ikke helt få - tilfælde, hvor den disciplinære forseelse har givet anledning til andre indgribende foranstaltninger, $f x$ overførsel til mere restriktivt regime, udgangskarantæne og politianmeldelse. Sådanne indgreb kan der ifølge disciplinærstrafbekendtgørelsen »efter omstændighederne tages hensyn [til] ved valget af disciplinærstraf «. ${ }^{31}$ Der er herved ganske vist sket en stramning, idet udgangspunktet før 2016 var det omvendte, da det hed i bekendtgørelsen, at i disse tilfælde kan der »kun ikendes disciplinærstraf i det omfang, afgørende ordens- eller sikkerhedsmæssige hensyn kræver det«. ${ }^{32}$ Men selv med den strammere formulering burde det være naturligt at overveje, om hensynet til orden og disciplin i fængslet ikke var tilstrækkeligt tilgodeset ved de øvrige (mærkbare) indgreb.

30. DfK's klageafgørelse af 21. april 2017 vedrørende afgørelser truffet den 3. og 4. oktober 2016 i Københavns Fængsler.

31. Bkg. nr. 105 af 30.01.2019 § 4.

32. Bkg. nr. 426 af 09.04.2015 §4. 


\section{Eksempel 6 (Jyderup Fængsels afgørelse af 30.10.2019):}

En indsat nægtede at afgive urinprøve og blev tillige fundet skyldig i indsmugling af $36,2 \mathrm{gram}$ hash. Forhørsledeen besluttede, at den indsatte skulle overføres til lukket regi, have tilbagekaldt sin udgangstilladelse i 6 måneder og politianmeldes med henblik på strafforfølgning samt yderligere ikendes strafcelle i 10 dage.

Det kunne have været overvejet, om hensynet til at sikre orden og sikkerhed i fængslet ikke var tilstrækkeligt tilgodeset med overførsel af den indsatte til lukket regi, en lang udgangskarantæne og en ny straffesag, således at det ikke havde været nødvendigt at tilføje 10 dages strafcelle.

Det kunne også diskuteres - generelt eller konkret - om det er nødvendigt (og forholdsmæssigt) at både at ikende strafcelle og at konfiskere genstande, som indsatte er i ulovlig besiddelse af i fængslet, men som er fuldt lovlige i det frie samfund, fx mobiltelefoner og tilbehør hertil (bl.a. simkort), cigaretter og lightere. Det ville måske være tilstrækkeligt af hensyn til orden og sikkerhed i fængslet enten at nøjes med konfiskation eller at kombinere en disciplinærstraf med inddragelse af genstandene og tilbagelevere dem til den indsatte, når han forlader fængslet ved udgang eller løsladelse, jf. DfK's udtalelse til ombudsmanden:

»Det forudsættes (...), at afgørelse af spørgsmål om konfiskation navnlig sker under iagttagelse af proportionalitetsgrundsætningen, så konfiskation undlades, hvis det må anses for et uforholdsmæssigt indgreb. (...)

Medmindre afgørende ordens- og sikkerhedsmæssige hensyn i institutionen kræver det, kan genstande og penge eventuelt i stedet (...) opbevares i institutionen i overensstemmelse med reglerne i genstandsbekendtgørelsen. «33

Det burde generelt overvejes, om det er nødvendigt - og rimeligt - at dobbeltstraffe indsatte ved disciplinærretlig og strafferetlig forfølgning for samme adfærd, som det i Danmark er praksis, bl.a. i sager om vold, trusler, narkotikabesiddelse, undvigelse og besiddelse af mobiltelefon. I Norge er udgangspunktet, at der ikke anvendes disciplinær reaktion samtidig med politianmeldelse, selv om det efter norsk ret ikke er absolut udelukket at gøre begge dele samtidigt (Storvik 2017, s. 312 ff.). I Sverige kan der i tilfælde, hvor en politianmeldelse fører til tiltalerejsning (lagföring) højst tildeles den indsatte en disciplinær advarsel (varning). ${ }^{34}$ I Danmark kan personale i forsvaret ikke pålægges disciplinaransvar, hvis der er hjemmel til eller behov for straf, jf. § 1, stk. 2, i den militære disciplinarlov.

De Europæiske Fængselsregler (Europarådet 2020, regel 63) fastslår, at en indsat aldrig må straffes to gange for den samme handling eller adfærd. I

33. Folketingets Ombudsmands rapport om inspektion den 07.02.2001 af Arresthuset $\mathrm{i}$ Aabenraa, s. 62.

34. Bemærkning til 12 kap. 2 § i Kriminalvårdens föreskrifter och allmänna råd om fängelse beslutade den 10 januari 2011 (med senere ændringer). 
kommentaren til reglerne understreges, at forbudet også gælder anvendelse af en disciplinær sanktion samtidig med en strafferetlig sanktion. ${ }^{35}$

Kessing (2019, s. 55 og 58 ff.) og Smit \& Snacken (2009, s. 303) har argumenteret for, at anvendelse af strenge disciplinære sanktioner ( $f x$ langvarig isolation, eventuelt suppleret med andre intensive og restriktive foranstaltninger) samtidig med strafferetlig forfølgning kan være omfattet af begrebet straffesager i EMRK art. 6 og dermed også af forbuddet mod dobbeltstraf (ne bis in idem) i konventions tillægsprotokol nr. 7, art. 4. Efter EMD's hidtidige praksis er kun disciplinære sanktioner, som forlænger frihedsberøvelsen, anerkendt som straffesager og dermed også omfattet af forbuddet mod dobbeltstraf.

\section{Konklusion og anbefalinger}

\subsection{Sammenfatning}

Analysen af administrativ praksis har vist, at disciplinærsager, som ikke er tilståelsessager, i reglen afgøres med en skriftlig indberetning (rapport) som det vægtigste - eller eneste - bevis og dermed i strid med principperne om bevisumiddelbarhed og mundtlighed. Afhøringer af rapportskrivere og andre vidner forekommer ikke. DfK har i sine klageafgørelser blåstemplet denne praksis, til trods for at direktoratet i vejledningen om behandlingen af sager om disciplinærstraf peger på, at det i nogle tilfælde vil være påkrævet at indhente yderligere indberetninger eller foretage afhøringer af personale eller medindsatte, og at det i visse tilfælde kan være nødvendigt at foretage genafhøring af såvel den indsatte som af vidner.

Spørgsmål om tilregnelighed, tilregnelse og objektive straffrihedsgrunde ses ikke at have været genstand for bevisførelse i de undersøgte sager.

Udmåling af straffene sker efter de udarbejdede skemaer over normalreaktioner. Det er sjældent, at skærpende eller formildende omstændigheder nævnes og tages i betragtning ved udmålingen. Forvaltningsretlige (formålsrelaterede) proportionalitetshensyn indgår tilsyneladende ikke i overvejelserne om sanktionsfastsættelsen. Der tages normalt heller ikke hensyn til, at den konkrete forseelse giver anledning til andre mærkbare indgreb i afsoningsforholdene ( $f x$ udgangskarantæne og tvangsoverførsel til mere restriktivt regime), eller til at der sker politianmeldelse med henblik på strafforfølgning. Det står i klar modsætning til praksis i vore nordiske nabolande (jf. ovenfor afsnit 5.2.3) samt til disciplinærretlig lovgivning for forsvaret og til internationale anbefalinger, at strafbare forhold begået af indsatte straffes dobbelt i form af både disciplinærretlig og strafferetlig sanktionering.

35. Europarådets Ministerkomités dokument CM(2020)17-add2 (20.02.2020), s. 40. 


\subsection{Anbefalinger}

Strafcelle er en streng og indgribende disciplinærstraf, hvis anvendelse må kræve et sikkert grundlag, jf. ombudsmandens bemærkning i en sag om strafcelle: » almindelighed antages det, at kravene til undersøgelsernes udstrækning og sikkerheden for de relevante oplysningers rigtighed øges, jo mere betydningsfulde eller indgribende afgørelser der er tale om « (FOB 2020-14; Fenger 2018, s. 490). Den ovenfor refererede praksisanalyse afslører et klart behov for justeringer i disciplinærprocessen med henblik på styrkelse af både faktum og jus i sagsbehandlingen.

Gennemgangen af retsgrundlaget i hovedafsnit 4 illustrerer, at juridiske vurderinger er væsentlige i disciplinærretsprocessen. Som tidligere nævnt var det indtil omkring 1980 altid jurister, som virkede som forhørsledere i disciplinærsager. Det vil være ideelt at vende tilbage til denne praksis, men mindre justeringer i den nuværende praksis kunne måske bringe praksis i bedre harmoni med de juridiske fordringer. For det første må det kræves, at nutidens forhørsledere bliver væsentligt bedre uddannet til varetagelsen af de juridiske led i disciplinærstraffeprocessen, dvs. til gennemførelse af disciplinærsagen i overensstemmelse med det foran beskrevne retsgrundlag.

For det andet kunne der med fordel indføres en ændret kompetenceordning, som bringer juridisk faglighed ind i processen. Forhørslederen kan (fortsat) have til opgave gennemføre undersøgelsen (forhøret) og kan tillige få beføjelse til at afgøre sagen med en advarsel eller en bøde. Hvis forhørslederen finder, at sagen efter praksis bør afgøres med strafcelle, skal han/ hun afgive indstilling herom til en jurist, som træffer afgørelse i sagen efter at have sikret sig, at sagen er behørigt oplyst.

Det anbefales, at DfK's vejledning udbygges væsentligt. Den danske vejledning fylder otte sider, medens eksempelvis den engelsk-walisiske vejledning, »Prisoner discipline procedures (adjudications)«, fylder 87 sider (PSI 05/2018). Da forhørslederopgaven lå hos en jurist, var det måske tilstrækkeligt at skrive i vejledningen (punkt 2), at »[h]erudover gælder forvaltningsloven og almindelige forvaltningsretlige grundsætninger«, men når opgaven nu er placeret hos forhørsledere uden juridisk uddannelse, er det nødvendigt nøje at beskrive de relevante retsgrundsætninger. Vejledningens beskrivelse af retsgrundlaget burde også udbygges med oplysning om relevante strafferetlige principper, ikke mindst princippet in dubio pro reo. I tidligere versioner af disciplinærstrafvejledningen har DfK henvist til en huskeliste, som var udarbejdet for forhørsledere ii arresterne på baggrund af en gennemgang af Folketingets Ombudsmands inspektioner. ${ }^{36}$ En sådan huskeliste burde ajourføres og indarbejdes i vejledningen.

Den elektroniske skabelon til forhørsprotokollater burde kunne forbedres og ledsages af en grundig vejledning med henblik på at gøre den mere brugervenlig for forhørslederne og bedre egnet som redskab for en juridisk forsvarlig gennemførelse af de disciplinærretlige forhør.

36. Senest i vejledning $\mathrm{nr} .30$ af 29.03.2012, punkt 1.1. 
Et oplagt forsøg på at begrænse brugen af strafcelle i danske fængsler ville være at bringe dansk ret på linje med norsk og svensk ret og i harmoni med disciplinærretlig lovgivning for forsvaret og med De Europæiske Fængselsregler (Europarådet 2020, regel 63) ved at afskaffe dobbeltbestrafning af strafbare gerninger. Overtrædelser som vold, trusler og besiddelse af narkotika, dopingmidler og mobiltelefoner anmeldes typisk til politiet og udløser samtidig mange disciplinærstraffe, typisk af længere varighed. Hjemlen til at ikende disciplinærstraffe for »upassende sprogbrug« kunne helt ophæves. De alvorligere tilfælde vil være omfattet af straffelovens $\S 121$ og bør politianmeldes, medens de mildere tilfælde må anses for beskyttet af ytringsfriheden efter EMRK art. 10. (Se Engbo 2019, s. 230 ff., om flere måder at reducere eller mildne brugen af strafcelle på).

Kontaktoplysninger

\section{Hans Jørgen Engbo: hjengbo@gmail.com.}

\section{Litteratur}

Andersen. J. (2014). Forvaltningsret. København: Karnov Group.

Christensen, B. (1997). Forvaltningsret. Opgaver, hjemmel, organisation. København: DJØF Forlag.

CPT (2011): 21st General Report of the European Committee for the Prevention of Turture and Inhuman or Degrading Treatment or Punishment. Strasbourg: Council of Europe.

Engbo, H.J. (2005). Straffuldbyrdelsesret. København: DJØF Forlag.

Engbo, H.J. (2019): Normalisering og isolation. I: Rua, M. \& P.S. Smith: Isolasjon. Et fengsel i fengselet. Oslo: Cappelen Damm Akademisk.

Europarådet (2020): Recommendation Rec(2006)2-rev of the Committee of Ministers to member States on the European Prison Rules. Adopted by the Committee of Ministers on 11 January 2006 at the 952 nd meeting of the Ministers' Deputies and revised and amended by the Committee of Ministers on 1 July 2020 at the 1380th meeting of the Ministers' Deputies.

Fenger, N. (2018): Forvaltningsret. København: DJøF Forlag.

FN (2018): United Nations Standard Minimum Rules for the Treatment of Prisoners (the Nelson Mandela Rules). Resolution adopted by the General Assembly on 17 December 2015.

Folketingets Ombudsmand (2020): Temarapport 2019 - Strafceller. Afgivet 05.05.2020.

Greve, V. (2002): Straffene. København: DJØF Forlag.

Greve, V. (2008): Juridiske konflikter. Afskedsforelæsning 28. marts 2008. Københavns Universitet.

Kessing, P.V. (2019): Strafcelle - isolation af indsatte i danske fængsler. I: Juristen, nr. 2, s. 51-61.

Mortensen, B.O.G (2009): Om proportionalitetsprincippet. I: Juridiske Emner 2009. Syddansk Universitet.

Nytrøen, I. (2019): Bruken av isolasjon i fengsel - fra en fengselsbetjents perspektiv. I: Rua, M. \& P.S. Smith: Isolasjon. Et fengsel i fengselet. Oslo: Cappelen Damm Akademisk.

Rentzmann, W., J.K. Mikkelsen \& A. Esdorf (2003): Straffuldbyrdelsesloven med kommentarer, 1. udgave. København: DJØF Forlag.

Schiøler, J. (2012). Straffuldbyrdelseslovens bestemmelser om indgreb over for indsatte. København: DJØF Forlag.

Schiøler, J. \& A. Dragsted (2017). Straffuldbyrdelsesloven med kommentarer, 2. udgave. København: DJØF Forlag.

Sivilombudsmannen (2019): Særskilt melding til stortinget om isolasjon og mangel på menneskelig kontakt i norske fengsler. Dokument 4:3 (2018/19). 
Smith, E., J. Jochimsen, M. Kistrup \& J.L. Poulsen (2005): Straffeprocessen. København: Forlaget Thomsen.

Smith, P.S., T. Horn, J.F. Nilsen \& M. Rua (2013). Isolasjon i skandinaviske fengsler. I: Kritisk juss 03-04 (Volum 39), s. 170-191. (På dansk i Social Kritik nr. 136/2013, s. 4-20.)

Smith, P.S. \& I. Koch (2019): Isolationens følgevirkninger - fra 1800-tallet til i dag. I: Isolasjon - Et fengsel i fengselet. Oslo: Cappelen Damm Akademisk.

Storvik, B.L. (2019): Straffegjenomføring. Oslo: Cappelen Damm Akademisk.

Toftegaard Nielsen, G. (2020): Straffesagens gang. København: DJØF Forlag.

Van Zyl Smit, D. \& s. Snacken (2009): Principles of European Prison Law and Policy. Oxford: Oxford University Press.

Verland, K. \& J. Christoffersen (2017): Isolationsfængsling gør fanger syge. https://dignity. dk/blog/isolationsfaengsling-goer-fanger-syge/ (læst 08.11.2020).

Westerhäll, L.V. (2006): Regel och skön i nordisk förvaltningsrätt. I: C. Henrichsen, s. Rønsholt \& P. Blume (red.): Forvaltningsretlige perspektiver. København: DJØF Forlag. 